\title{
PROSES PERANCANGAN RUANG BIMBINGAN BELAJAR "MAKHOTA" DI KRUKUT JAKARTA
}

\author{
Susinety Prakosoํㅜ, Felia Srinaga ${ }^{1}$, Julia Dewi ${ }^{1}$, Dicky Tanumihardja ${ }^{1}$, Alvar Mensana ${ }^{1}$ \\ ${ }^{1}$ Program Studi Arsitektur, Fakultas Desain, Universitas Pelita Harapan \\ susinety.prakoso@uph.edu, felia.srinaga@uph.edu, julia.dewi@uph.edu, \\ dicky.tanumihardja@uph.edu, alvar.mensana@uph.edu
}

\begin{abstract}
Abstrak
Tulisan ini bertujuan untuk menjelaskan proses perancangan kembali ruang bimbingan belajar "Mahkota" di daerah Krukut Jakarta Barat. Perancangan kembali ruang bimbingan belajar Mahkota merupakan bagian dari kegiatan PkM program studi Arsitektur Universitas Pelita Harapan bekerja sama dengan mitra Yayasan Beritakan Kasih. Perancangan ruang bimbingan belajar ini mendesak untuk dilakukan karena 1) bangunan bimbel terlihat kumuh; 2) ruang kelas terlalu kecil; 3) ventilasi ruang kelas yang buruk; 4) bangunan bimbel terkena banjir. Lokasi bimbel yang terletak di permukiman padat penduduk memberikan peluang pada perancangan kembali bimbel untuk berfungsi sebagai tempat belajar dan bermain bagi anak-anak yang kurang mampu secara ekonomi, untuk memperoleh pelajaran tambahan sekolah. Rancangan kembali ruang bimbingan belajar Mahkota meliputi penataan kembali layout/denah ruang belajar, penataan ruang eksterior dan ruang interior bimbel. Proses perancangan ruang bimbingan belajar menggunakan pendekatan partisipasi, dengan tujuan untuk menghasilkan rancangan yang peka terhadap kebutuhan anak serta bermakna bagi anak. Kegiatan PKM dilakukan dalam empat tahap, yaitu 1) community background research; 2) mengumpulkan pandangan anak dan orang dewasa; 3) membahas material yang terkumpul; 4) memutuskan apa yang perlu diteruskan dan diubah. Luaran kegiatan PKM ini adalah rancangan final gambar desain ruang bimbingan belajar dalam bentuk gambar kerja, dan gambar presentasi yang dapat digunakan oleh pihak Yayasan untuk melaksanakan pembangunan fisik di lapangan.
\end{abstract}

Kata Kunci: Proses perancangan, ruang bimbingan belajar, proses partisipasi, anak

PENDAHULUAN

Perancangan kembali ruang bimbingan belajar (bimbel) "Mahkota" di daerah Krukut Jakarta Barat merupakan kegiatan pengabdian kepada masyarakat Program Studi Arsitektur Universitas Pelita Harapan dengan mitra Yayasan Beritakan Kasih Tuhan (Berkat). Bimbel Mahkota berada di lahan berukuran $12.35 \mathrm{~m} \times 5.35 \mathrm{~m}\left(66 \mathrm{~m}^{2}\right)$, terletak di Jl. Kesederhanaan No. 10, RT. 009 /04, Kelurahan Keagungan, Kecamatan Taman Sari, Krukut Jakarta
Barat. Bimbel Mahkota berada di lingkungan permukiman padat di wilayah Krukut Jakarta Barat. Lingkungan sekitar lokasi terdapat banyak anakanak usia sekolah dasar yang kurang mampu secara ekonomi untuk mendapatkan pelajaran tambahan di luar sekolahnya. Bimbel di lokasi ini bertujuan untuk memberikan tambahan pelajaran, membantu anakanak yang kesulitan belajar, dan memberikan pelatihan-pelatihan yang dibutuhkan oleh anak-anak.

Kondisi eksisting bimbel Mahkota adalah berupa bangunan sangat sederhana dengan 3 (tiga)

$$
\text { Pendidikan }
$$

1012 
ruangan kecil berukuran $4.15 \mathrm{~m} \times 2.15 \mathrm{~m}$ yang digunakan sebagai ruang kelas, tidak dilengkapi dengan peralatan belajar mengajar yang memadai dan tidak mencukupi untuk mewadahi seluruh kegiatan bimbel. Tiga ruang kelas tersebut digunakan oleh murid TK s/d SD kelas 1, murid SD kelas 2 s/d 4 SD, dan murid 1 s/d 3 SMP. Bimbel Mahkota digunakan oleh 25 anak-anak usia 5 s/d 14 tahun untuk aktivitas belajar setelah pulang sekolah, yang dimulai dari jam 7 hingga 9 malam. Denah bimbel dapat di lihat pada Gambar 1.

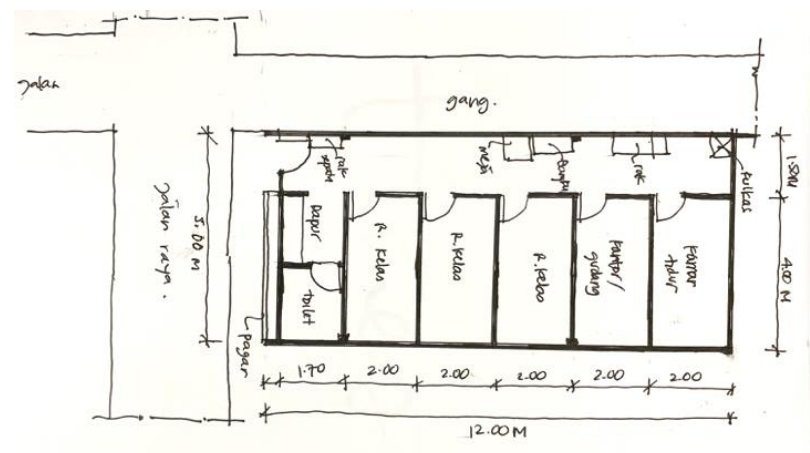

Gambar 1. Denah bimbel Mahkota

Berdasarkan observasi awal (Gambar 2), permasalahan mitra adalah 1) bangunan bimbel terlihat kumuh; 2) ruang kelas terlalu kecil; 3) ventilasi ruang kelas yang buruk; 4) bangunan bimbel terkena banjir; 5) ruang tidur keluarga pengurus bimbel (suami istri dengan 1 bayi) dalam kondisi tidak layak huni. Untuk itu, pihak mitra menganggap perlu untuk segera membenahi bangunan yang ada untuk menjadi lebih baik, nyaman, dan dapat menampung aktivitas anak-anak belajar. Bimbel yang terletak di permukiman padat penduduk juga memiliki potensi untuk menjadi tempat belajar dan bermain bagi anak-anak yang kurang mampu secara ekonomi untuk memperoleh pelajaran tambahan sekolah. Permasalahan lain dari bangunan bimbel Mahkota adalah terbatasnya ruang untuk menampung beberapa aktivitas, seperti area tempat duduk-duduk untuk menunggu, area untuk bermain dan area untuk membaca. Untuk itu interior dan eksterior bimbel Mahktoa dianggap perlu dan mendesak untuk di tata ulang.

Menanggapi permasalahan yang ada, maka kegiatan PKM ini bertujuan untuk melakukan penataan kembali kondisi fisik eksterior dan interior
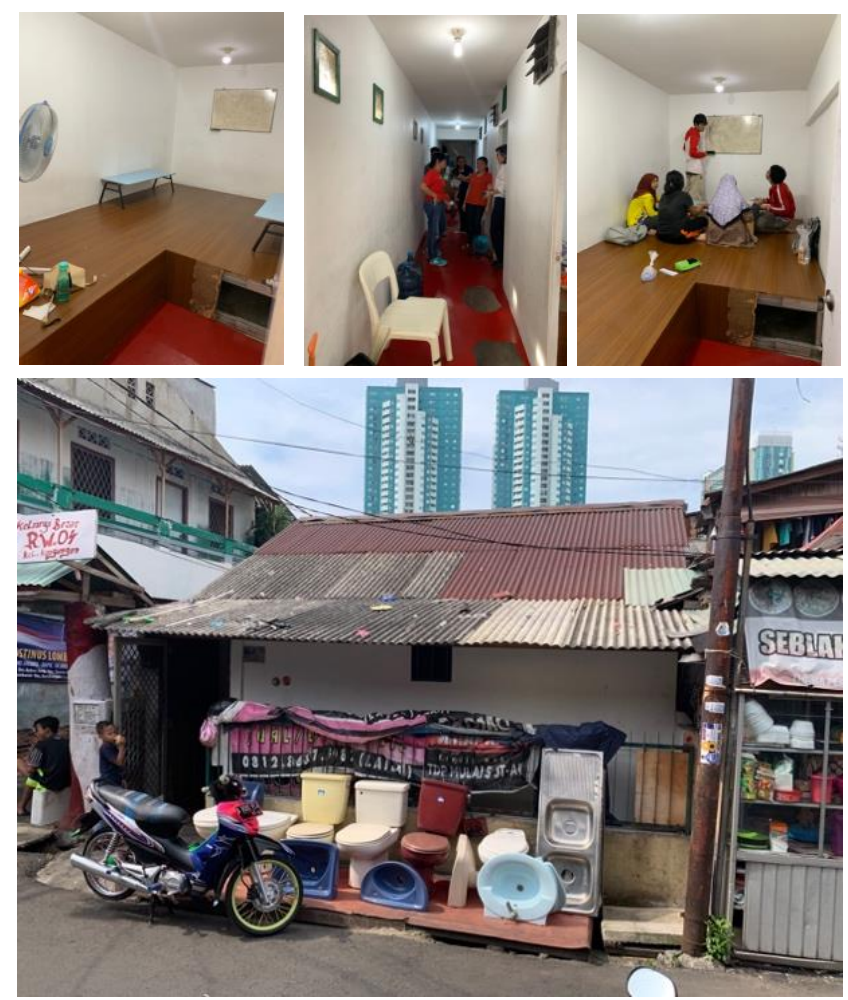

bimbel, yang meliputi penambahan lantai bangunan untuk menampung kebutuhan ruang pengurus bimbel, memperbesar ruang kelas, penataan eksterior bangunan, serta penatan ventilasi ruang kelas.

Gambar 2. Suasana interior (atas) dan eksterior (bawah) bimbel Mahkota

\section{PENDEKATAN PARTISIPASI DALAM PROSES PERANCANGAN}

Demi perancangan kembali bimbel Mahkota lebih berkelanjutan di masa depan, maka pengambilan keputusan dalam proses perancangan bimbel perlu melibatkan partisipasi anak sebagai pengguna bimbel yang utama. Melibatkan anak pengguna bimbel dalam proses perancangan kembali bimbel berarti anak diberi kesempatan untuk menjadi agen perubahan suatu lingkungan binaan secara positif (Malone, 2017). Ditambah lagi, melibatkan anak dalam proses perencanaan dan perancangan suatu lingkungan binaan dapat menjadi suatu indikator bagaimana suatu desain telah mengimplementasi insiatif desain ramah anak (Malone, 2017).

Melibatkan anak dan remaja sebagai

Pendidikan

1013 
partisipan dalam proses penilaian, perencanaan, perancangan, pengawasan dan pengelolaan lingkungan binaan telah banyak ditunjukkan dalam berbagai kasus desain lingkungan binaan dan perbaikan ruang serta bangunan, seperti penelitianpenelitian yang dilakukan oleh Alparone and Rissotto (2001); Atmodiwirjo and Yatmo (2017); Derr (2015); Derr, Chawla, Mintzer, Cushing, and Van Vliet (2013); Ghaziani (2008); Green (2012); Rismanchian and Rismanchian (2007). Partisipasi merupakan "an essential principle of human rights and a working practise of citizenship for all people. The affirmation of the right of children to participate is one of the guiding principles and most progressive innovations of the Convention on the Rights of the Child" (Brederode-Santos, Claeys, Fazah, Schneider, \& Szelenyi, 2009, p. 254). Pendekatan partisipasi merupakan pendekatan demokratis dimana orang dewasa (perancang) menghormati kemampuan anak dalam mengambil keputusan dan mengakui anak sebagai rekan kerja dalam pengambilan keputusan.

Partisipasi anak dalam kegiatan ini bukan hanya sekedar tokenism, dimana anak hanya diminta pendapatnya, tetapi anak tidak memiliki pengaruh akan sesuatu atau bagaimana kontribusi mereka digunakan (Roger A. Hart, 1992). Partisipasi anak menurut Roger A Hart (2013) minimal dimulai dari tangga ke empat yaitu assigned but informed hingga yang tertinggi di tangga ke delapan yaitu childinitiated, shared decisions with adults. Kegiatan PkM ini menerapkan partisipasi anak di tangga keempat, yaitu assigned but informed.

Beberapa persyaratan penting dalam menjalankan proses partisipasi assigned but informed (Roger A. Hart, 1992) yang dilaksanakan dalam kegiatan PkM ini adalah: 1) Setiap anak mengetahui dan memahami tujuan kegiatan; 2) Setiap anak mengetahui siapa pengambil keputusan dalam perancangan kembali bimbel Mahkota dan mengapa perlu ada perancangan kembali bimbel Mahkota; 3) Setiap anak mememiliki peran yang berarti, bukan hanya berperan sebagai pengguna; 4) Setiap anak dengan rela berperan aktif sebagai sukarelawan dalam kegiatan ini setelah tujuan kegiatan ini dijelaskan dan dapat dipahami dengan baik.

\section{METODE}

Proses untuk menghasilkan rancangan kembali ruang bimbingan belajar dilakukan melalui beberapa tahap. Tahap pertama adalah melakukan background research untuk memahami komunitas yang diamati (Derr, Chawla, \& Mintzer, 2018). Tujuannya adalah untuk memahami tempat dan komunitas dimana kegiatan PkM ini akan dilakukan. Teknik yang digunakan adalah melalui wawancara pengelola dan pengurus bimbel, observasi kondisi fisik, sosial dan ekonomi bimbel, serta dokumentasi foto kondisi eksisting. Tahapan ini adalah tahapan pendahuluan sebelum proses partisipatori dengan anak dilakukan.

Tahap ke dua adalah 'Gathering children's and adult's perspectives'(Clark, 2010) atau mengumpulkan informasi dari anak-anak dan guru terkait dengan 'existing spaces' dan 'possible spaces'. Teknik yang digunakan pada tahap ini adalah melalui wawancara, survey dan pengisian kuesioner. Semua pecahan informasi yang dikumpulkan pada tahap ini, akan didiskusikan, direfleksikan dan diinterpretasikan menjadi serangkain informasi terkait dengan program ruang dan kualitas ruang yang diinginkan pada rancangan ruang bimbel baru. Luaran tahap ini akan menjadi masukan dalam proses menuju tahapan berikutnya.

Tahap ke tiga adalah 'discussing (reviewing) the material' (Clark, 2010) atau mengumpulkan dan menyusun semua pecahan informasi yang dikumpulkan melalui tahapan sebelumnya untuk didiskusikan, direfleksikan dan diinterpretasikan bersama-sama secara internal oleh tim. Luaran tahapan ini adalah desain awal bimbel.

Tahap selanjutnya adalah 'deciding on areas of continuity and change' (Clark, 2010). Langkah ini dilakukan melalui diskusi dengan Yayasan Berkat, agar rancangan ruang bimbel yang baru sesuai dengan anggaran dan jadwal kerja yang telah ditetapkan oleh Yayasan. Luaran tahap ini adalah gambar rancangan yang akan dimanfaatkan dalam proses perhitungan anggaran dan konstruksi di lapangan.

\section{HASIL DAN PEMBAHASAN}

\section{Evaluasi kondisi eksisting bimbel}


Evaluasi kondisi eksisting bimbel dilakukan terhadap 14 murid dan 6 guru. Hasil rekapitulasi evaluasi kondisi eksisting bimbel oleh murid dan guru dapat di lihat pada Gambar 3. Hasil evaluasi mengungkapkan ada dua tanggapan murid dan guru terhadap kondisi bimbel, yaitu tanggapan negatif dan tanggapan positif murid dan guru terhadap bimbel.

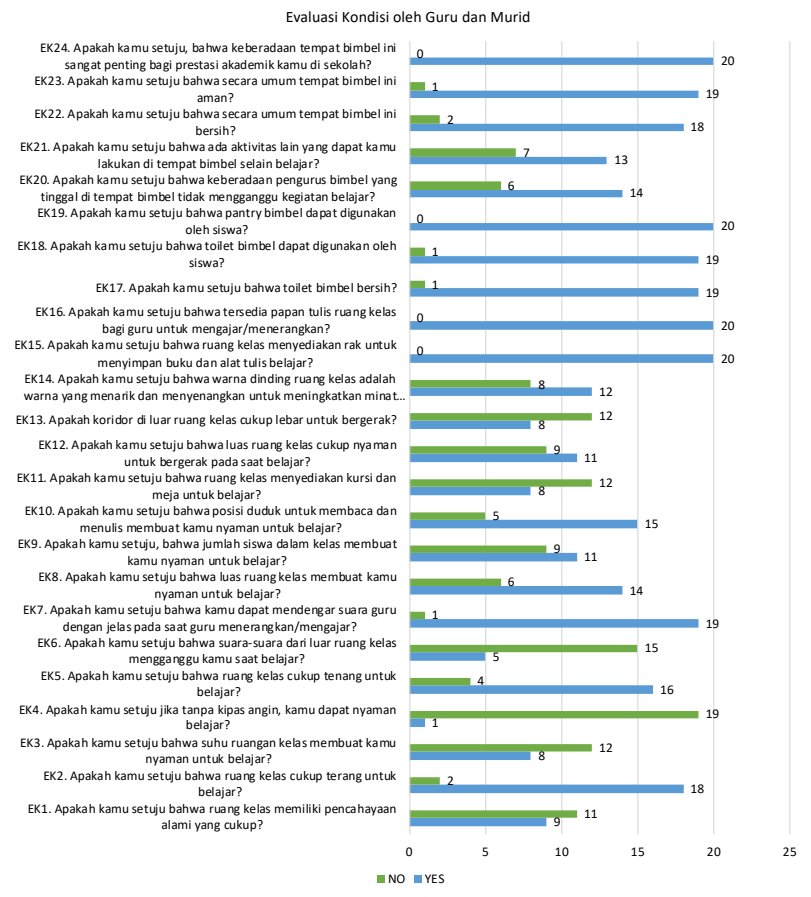

Gambar 3. Rekapitulasi hasil evaluasi kondisi eksisting bimbel oleh murid dan guru

Tanggapan negatif murid dan guru terhadap bimbel adalah: 1) sebanyak 55\% responden menganggap ruang kelas tidak memiliki pencahayaan alami; 2) $60 \%$ responden menyatakan suhu ruangan tidak nyaman untuk belajar (panas); 3) 95\% responden tidak dapat belajar tanpa kipas angin; 4) $60 \%$ responden menyatakan ruang kelas tidak dilengkapi dengan peralatan belajar yang cukup (meja terbatas dan tidak ada kursi); dan 5) 60\% responden menyatakan koridor ruang kelas sempit untuk bergerak.

Tanggapan positif murid dan guru terhadap bimbel adalah 1) lampu di ruang kelas dianggap $90 \%$ responden cukup terang untuk belajar; 2) ruang kelas dianggap cukup tenang untuk belajar oleh $80 \%$ responden dan $70 \%$ responden menyatakan suarasuara dari luar bimbel tidak mengganggu kegiatan belajar mengajar; 3) suara guru dalam kelas jelas terdengar oleh $95 \%$ responden; 4) luas ruang kelas tidak dianggap sempit untuk belajar oleh 55\% responden dan $70 \%$ responden merasa dapat bergerak di dalam kelas dengan baik; 5) jumlah murid dianggap tidak terlalu banyak dalam 1 kelas oleh 55\% responden; 6) posisi belajar di lantai dianggap tidak mengganggu kegiatan belajar oleh 75\% responden; 7) warna dinding putih kelas tidak dianggap masalah dalam menurunkan minat belajar/mengajar $60 \%$ responden; 8) $100 \%$ responden menyatakan ruang kelas menyediakan rak buku dan papan tulis untuk belajar mengajar; 9) toilet bimbel bersih dan dapat digunakan oleh 95\% responden; 10) pantry bimbel dapat digunakan oleh $100 \%$ responden; 11) keberadaan pengurus bimbel tidak menggangu kegiatan belajar mengajar oleh $70 \%$ responden; 12) 65\% responden menginginkan ada kegiatan lain selain bimbel; 13) secara umum, bimbel dianggap aman (95 responden) dan bersih (90\% responden); dan 14) $100 \%$ responden menanggap bimbel merupakan tempat yang penting bagi prestasi akademik mereka.

\section{Prioritas kebutuhan ruang bimbel}

Diskusi dan survey terhadap 14 murid dan 6 guru juga mengungkapkan kemungkinankemungkinan ruang (possible spaces) bimbel yang diharapkan oleh murid dan guru. Kemungkinankemungkinan ruang bimbel tersebut diurutkan berdasarkan prioritasnya. Hasilnya diperoleh dua tingkat prioritas kebutuhan ruang bimbel (Gambar 4).

Ruang-ruang yang menjadi prioritas pertama oleh murid dan guru adalah ruang kelas dengan kriteria: 1) ada bukaan untuk pencahayaan alami; 2) ada lampu cukup terang untuk pencahayaan malam hari; 3) ada AC dan kipas angin; 4) ada jendela untuk ventilasi udara; 5) dinding dengan warna menarik untuk menstimulasi minat belajar dan dapat menjadi media belajar; 6) memiliki perlengkapan belajar, seperti meja, kursi, papan tulis, rak penyimpan buku dan alat tulis; 7) cukup luas untuk bergerak. Selain ruang kelas, murid dan guru juga mengganggap bimbel perlu memiliki: 1) koridor dengan hiasan dinding menarik (materi belajar): 2) ruang tunggu; 3 ) ruang buku/baca; 4) rak sepatu/sandal; 5) toilet; 6) pantry; 7) kantor dan gudang penyimpan barang; serta 8) tempat tinggal pengurus bimbel. Sedangkan

$$
\text { Pendidikan }
$$

1015 
ruang-ruang yang dianggap prioritas ke dua oleh murid dan guru adalah kebutuhan akan jendela di ruang kelas untuk pandangan keluar ruangan, serta adanya ruang bermain untuk kegiatan menunggu diantara waktu bimbel.

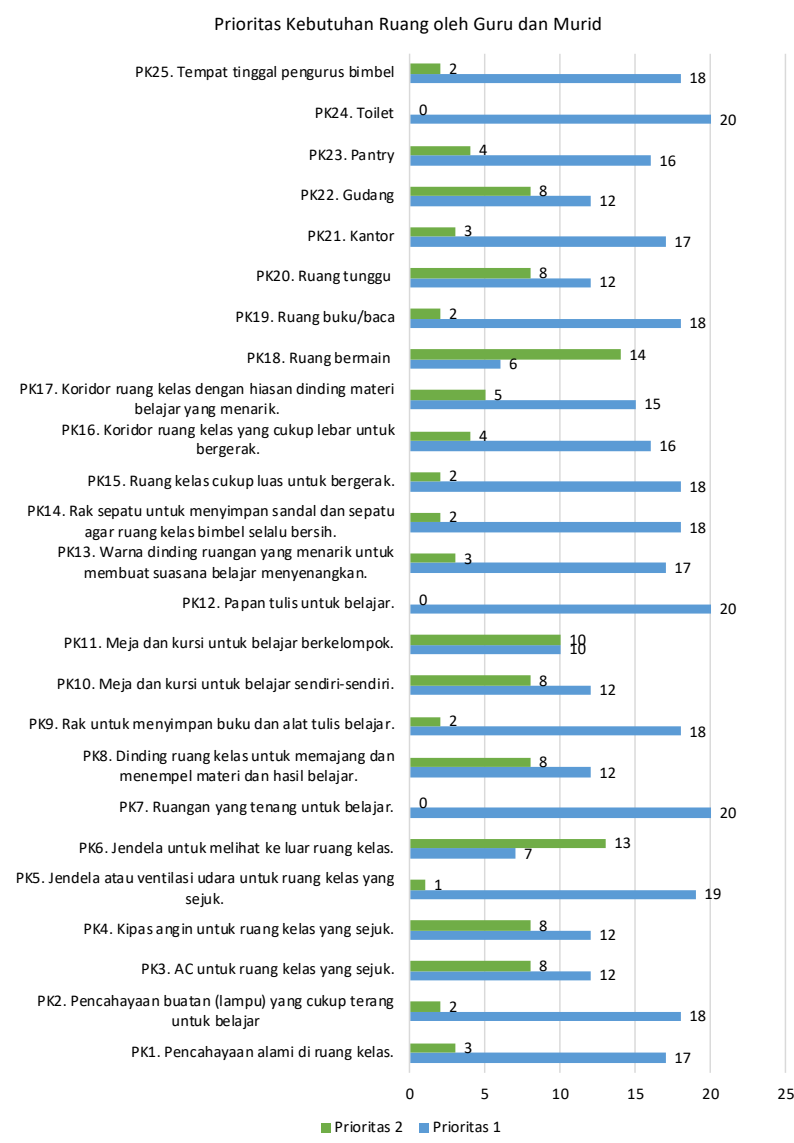

Gambar 4. Rekapitulasi prioritas kebutuhan ruang bimbel oleh murid dan guru

\section{Rekomendasi desain ruang bimbel}

Permasalahan terbesar bimbel yang dikeluhkan oleh responden adalah 1) kualitas ruang dalam terutama panas dan kurangnya pencahayaan alami; 2) koridor yang sempit sebagai penghubung dan sirkulasi antar ruang kelas; dan 3) keterbatasan perlengkapan belajar mengajar kelas (meja dan kursi belajar). Walaupun luas ruang kelas dianggap cukup oleh 55\% responden, namun $90 \%$ responden menginginkan ruang kelas yang lebih besar dari kondisi eksisting sekarang. Hasil wawancara dan diskusi dengan guru dan murid serta pengurus/pengelola, diketahui bahwa: 1) tinggi plafon ruang kelas terlalu rendah, terutama bagi siswa remaja dan guru untuk dapat berdiri tegak; 2) bimbel terendam banjir setinggi $\pm 40-50 \mathrm{~cm} ; 3$ ) ada keingingan pengelola untuk menambah kegiatan di siang hari (misalnya musik, dll) selain kegiatan bimbel di malam hari.

Oleh karena itu, rekomendasi tim untuk perancangan kembali Bimbel Mahkota adalah sebagai berikut: 1) memiliki minimal 3 ruang kelas dengan ukuran minimal 2mx4m (lebih besar lebih baik); 2) ruang kelas memiliki pengudaraan yang lebih baik, tidak pengap, dan penerangan yang baik; 3) memiliki ruang multiguna (di luar ruang kelas) yang dapat dimanfaatkan untuk menunggu, membaca, bermain, dll; 4) memiliki fasilitas seperti toilet, pantry, kantor dan gudang; 5) memiliki perlengkapan belajar seperti rak buku/alat tulis, meja \& kursi, papan tulis, panel untuk dekorasi dinding ruang kelas maupun koridor; 6) kamar tidur bagi pengurus (suami istri dan bayi) tetap dipertahankan; 7) warna ruang bimbel secara umum memberikan suasana menyenangkan untuk belajar; 8) bangunan bimbel diharapkan tidak terendam banjir.

\section{Rancangan akhir bimbel}

Pendekatan partisipasi yang dilakukan dalam proses perancangan kembali bimbel menghasilkan rancangan awal dan rancangan akhir bimbel. Rancangan awal bimbel diperoleh melalui pengolahan internal tim atas rekomendasi desain ruang bimbel. Selanjutnya usulan desain tersebut diolah menjadi gambar-gambar desain awal dalam bentuk denah, tampak, potongan dan suasana interior dan eksterior bimbel.

Desain awal bimbel selanjutnya dikonsultasikan ke pihak mitra untuk mendapatkan tanggapan. Tanggapan pihak mitra terhadap desain awal bimbel adalah sebagai berikut: 1) bangunan bimbel 2 (dua) lantai disetujui dan dipahami perlu dan penting untuk mewadahi berbagai aktivitas bimbel pada saat sekarang maupun yang akan datang; 2) ukuran bukaan di samping dan depan bangunan bimbel diharapkan untuk dapat diperkecil demi ketenanganan dan konsentrasi belajar murid, namun tidak mengurangi kenyamanan

Pendidikan 1016 
ventilasi/pengudaraan ruang dalam; 3) ekspresi bangunan bimbel diharapkan dapat diselaraskan dengan lingkungan dimana bimbel berada; 4) ruang tinggal pengurus bimbel disetujui berada di lantai dua.

Mitra juga menyatakan komitment untuk segera melakukan pekerjaan konstruksi bangunan bimbel dalam dua tahap. Tahap pertama akan melengkapi ruang kelas bimbel dengan $\mathrm{AC}$ dan furniture dasar ruang kelas, demi kenyamanan belajar mengajar. Tahap kedua melakukan konstruksi bangunan bimbel sesuai rancangan akhir bimbel di masa liburan sekolah dan tidak ada aktivitas bimbel.

Hasil konsultasi dengan mitra, menghasilkan rancangan akhir bimbel (Gambar 5 dan Gambar 6) sebagai berikut: 1) bangunan bimbel menjadi 2 lantai. Hal ini dikarenakan untuk memenuhi kebutuhan ruang bimbel; 2) mempertahankan tiga ruang kelas dan memperbesar ukurannya dari $2 \mathrm{~m} \mathrm{x}$ $4,8 \mathrm{~m}$ menjadi $2,6 \mathrm{~m} \times 4,8 \mathrm{~m}$; 3 ) menerapkan elemen bukaan berlubang kecil (roster) pada dinding sepanjang bangunan bimbel yang berfungsi untuk sebagai sirkulasi udara namun membatasi visual ruang dalam bimbel ke arah luar bimbel dan sebaliknya; 4) menempatkan ruang tinggal keluarga pengurus bimbel di lantai dua, demi pertimbangan privasi; 5) memanfaatkan ruang di bawah tangga sebagai ruang tunggu dan ruang baca/buku; 6) mempertahankan letak toilet dan pantry dengan pertimbangan efisiensi sistem utilitas bangunan; 7)

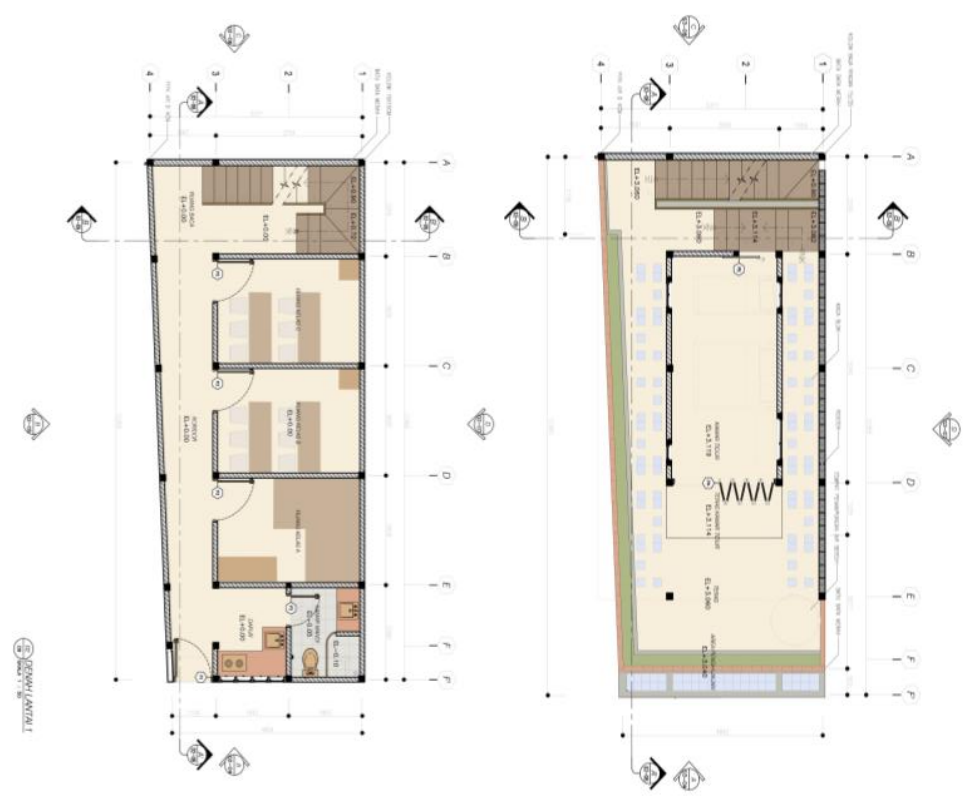

membuat desain tampak bimbel yang tidak kontras, namun menyatu dengan lingkungan sekitarnya dengan pemilihan material dan bentuk atap yang selaras dengan lingkungannya.

Gambar 5. Denah rancangan akhir bimbel 

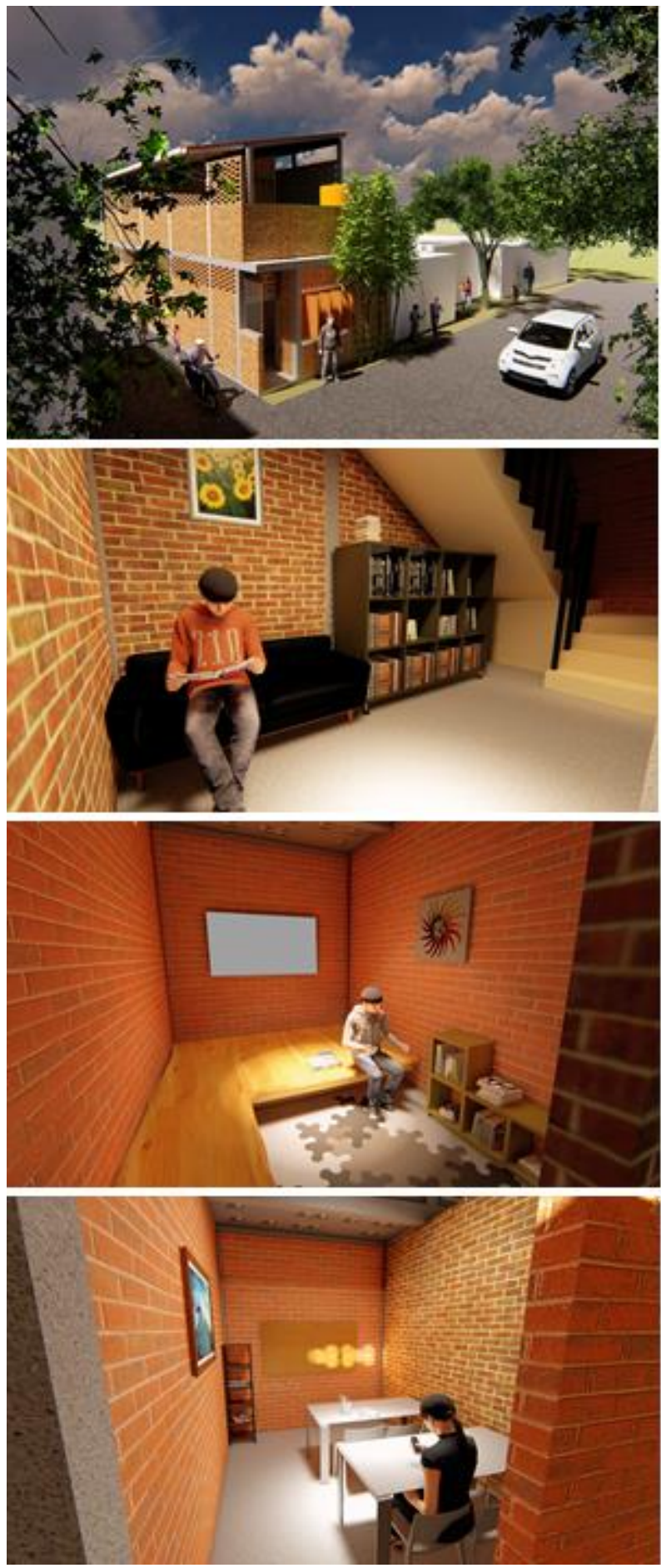

Gambar 6. Suasana eksterior dan interior bimbel

\section{KESIMPULAN}

Perancangan kembali bimbel Mahkota bertujuan untuk memperbaiki kondisi bangunan bimbel yang kurang layak untuk dijadikan sebagai tempat belajar anak-anak yang lebih nyaman. Agar perancangan kembali bangunan bimbel lebih peka terhadap kebutuhan anak serta bermakna bagi anak, maka proses perancangan kembali bangunan bimbel menerapkan pendekatan partisipasi assigned but informed (Roger A. Hart, 1992), yang dilaksanakan dalam beberapa tahap.

Walaupun pendekatan partisipasi yang dilaksanakan dalam kegiatan ini hanya ada di tangga ke-4 assigned but informed (Roger A. Hart, 1992), namun kegiatan survey dan kuesioner yang dilaksanakan bersama anak-anak dan guru tetap memperhatikan persyaratan-persyaratan penting pelaksanaan proses partisipasi dengan anak, yaitu 1) setiap anak dan guru mengetahui dan memahami tujuan pengambilan survey dan kuesioner; 2) setiap anak dan guru mengetahui mengapa perlu ada perancangan kembali bimbel Mahkota dan mengetahui pengambil keputusan desain baru bimbel ada di tangan Yayasan Berkat; 3) tim memahami bahwa hasil survey dan kuesioner adalah berarti dan penting demi keberlanjutan bimbel. Oleh karena itu setiap keputusan desain memperhatikan suara anak dan guru; 4) setiap anak dan guru menyambut dengan sukarela untuk berperan aktif dalam kegiatan ini.

Hasil dari pendekatan partisipasi yang dilakukan dalam proses perancangan kembali bimbel telah menghasilkan rancangan akhir bimbel yang lebih baik. Bangunan bimbel menjadi 2 lantai demi memenuhi kebutuhan-kebutuhan aktivitas bimbel. Ruang kelas diperluas untuk dapat mengakomodasi ruang gerak belajar mengajar yang lebih baik. Menempatkan ruang tidur privat pengurus bimbel di lantai 2 (dua) demi privasi. Bangunan bimbel menerapkan bentuk bukaan kecil dalam bentuk roster demi memperbaiki ventilasi ruang dalam bimbel, namun membatasi visual ke dalam/luar bimbel demi ketenangan belajar. Ekspresi desain bangunan bimbel dibuat untuk selaras dengan lingkungannya.

Saran untuk keberlanjutan kegiatan pengabdian pada masyarakat ini adalah perlu ada proses evaluasi terhadap bagaimana rancangan Pendidikan 1018 
bimbel digunakan oleh anak- anak dan guru. Perlu ada penilaian untuk menilai sejauh mana keberhasilan pendekatan partisipasi dalam mendukung keberhasilan tujuan rancangan bimbel yang peka terhadap kebutuhan anak dan bermakna bagi anak.

\section{UCAPAN TERIMAKASIH}

Kegiatan Pengabdian kepada Masayarakat ini dapat terlaksana karena dukungan LPPM UPH dengan nomor kontrak PM-004-SoD/I/2019.

\section{REFERENSI}

Alparone, F. R., \& Rissotto, A. (2001). Children's Citizenship and Participation Models: Participation in Planning Urban Spaces and Children's Councils. Journal of community \& applied social psychology, 11(6), 421-434.

Atmodiwirjo, P., \& Yatmo, Y. A. (2017). Children's Participation in Library Space Improvement Programme. Asian Journal of Environment-Behaviour Studies, 2(4), 21-31.

Brederode-Santos, M. E., Claeys, J., Fazah, R., Schneider, A., \& Szelenyi, Z. (2009). Compasito: Manual on Human Rights Education for Children Second Edition. Budapest: Directorate of Youth and Sport of the Council of Europe.

Clark, A. (2010). Transforming Children's Spaces: Children's and Adult's Participation in Designing Learning Environments. London \& New York: Routledge.

Derr, V. (2015). Integrating Community Engagement and Children's Voices into Design and Planning Education. CoDesign, 11(2), 119-133.

Derr, V., Chawla, L., \& Mintzer, M. (2018). Placemaking with Children and Youth: Participatory Process for Planning Sustainable Communities. New York: New Village Press.

Derr, V., Chawla, L., Mintzer, M., Cushing, D. F., \& Van Vliet, W. (2013). A City For All Citizens: Integrating Children and Youth From Marginalized Populations Into City Planning. Buildings, 3(3), 482-505.
Ghaziani, R. (2008). Children's Voices: Raised Issues For School Design. Co-Design, 4(4), 225-236.

Green, C. (2012). Listening to Children: Exploring Intuitive Strategies and Interactive Methods in A Study of Children's Special Places. International Journal of Early Childhood, 44(3), 269-285.

Hart, R. A. (1992). Innocenti Essays No. 4: Children's Participation from Tokenism to Citizenship. Italy: Unicef.

Hart, R. A. (2013). Children's participation: The theory and practice of involving young citizens in community development and environmental care: Routledge.

Malone, K. (2017). Child Friendly Cities: A Model of Planning for Sustainable Development. In K. Bishop \& L. Corkery (Eds.), Designing Cities with Children and Young People: Beyond Playgrounds and Skate Parks (pp. 11-23). New York and London: Taylor \& Francis.

Rismanchian, O., \& Rismanchian, A. (2007). Children Participation in Planning Processes: The Case of Child Friendly City Project in PostEarthquake Bam, Iran. Urban Design International, 12(2-3), 143-154. 